\title{
Neolithic crannogs: rethinking settlement, monumentality and deposition in the Outer Hebrides and beyond
}

\section{Duncan Garrow ${ }^{1, *} \&$ Fraser Sturt $^{2}$}

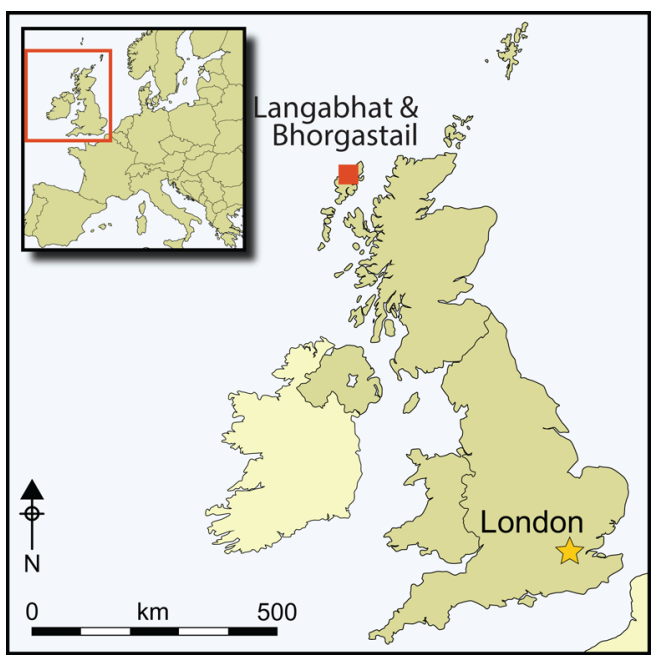

Artificial islets, or crannogs, are widespread across Scotland. Traditionally considered to date to no earlier than the Iron Age, recent research has now identified several Outer Hebridean Neolithic crannogs. Survey and excavation of these sites has demonstratedfor the first time - that crannogs were a widespread feature of the Neolithic and that they may have been special locations, as evidenced by the deposition of material culture into the surrounding water. These findings challenge current conceptualisations of Neolithic settlement, monumentality and depositional practice, while suggesting that other 'undated' crannogs across Scotland and Ireland could potentially have Neolithic origins.

Keywords: Scotland, Outer Hebrides, Neolithic, crannog, artificial islet, deposition, underwater archaeology

\section{Introduction}

Crannogs - artificial islands constructed in lakes and sea inlets - are a geographically widespread category of archaeological site in Scotland and Ireland. Over 570 island dwellings have been recorded in Scotland, including both 'crannogs' and 'island duns' (Figure 1; for a discussion of why these site types should be considered together, see Lenfert 2013:

1 Department of Archaeology, University of Reading, Whiteknights Box 227, Reading RG6 6AB, UK

2 Archaeology, Avenue Campus, University of Southampton, Highfield, Southampton SO17 1BF, UK

* Author for correspondence (Email: d.j.garrow@reading.ac.uk)

(C) Antiquity Publications Ltd, 2019. This is an Open Access article, distributed under the terms of the Creative Commons Attribution licence (http://creativecommons.org/licenses/by/4.0/), which permits unrestricted reuse, distribution, and reproduction in any medium, provided the original work is properly cited.

ANTIQUITY 93369 (2019): 664-684

https://doi.org/10.15184/aqy.2019.41 
Neolithic crannogs: settlement, monumentality and deposition in the Outer Hebrides
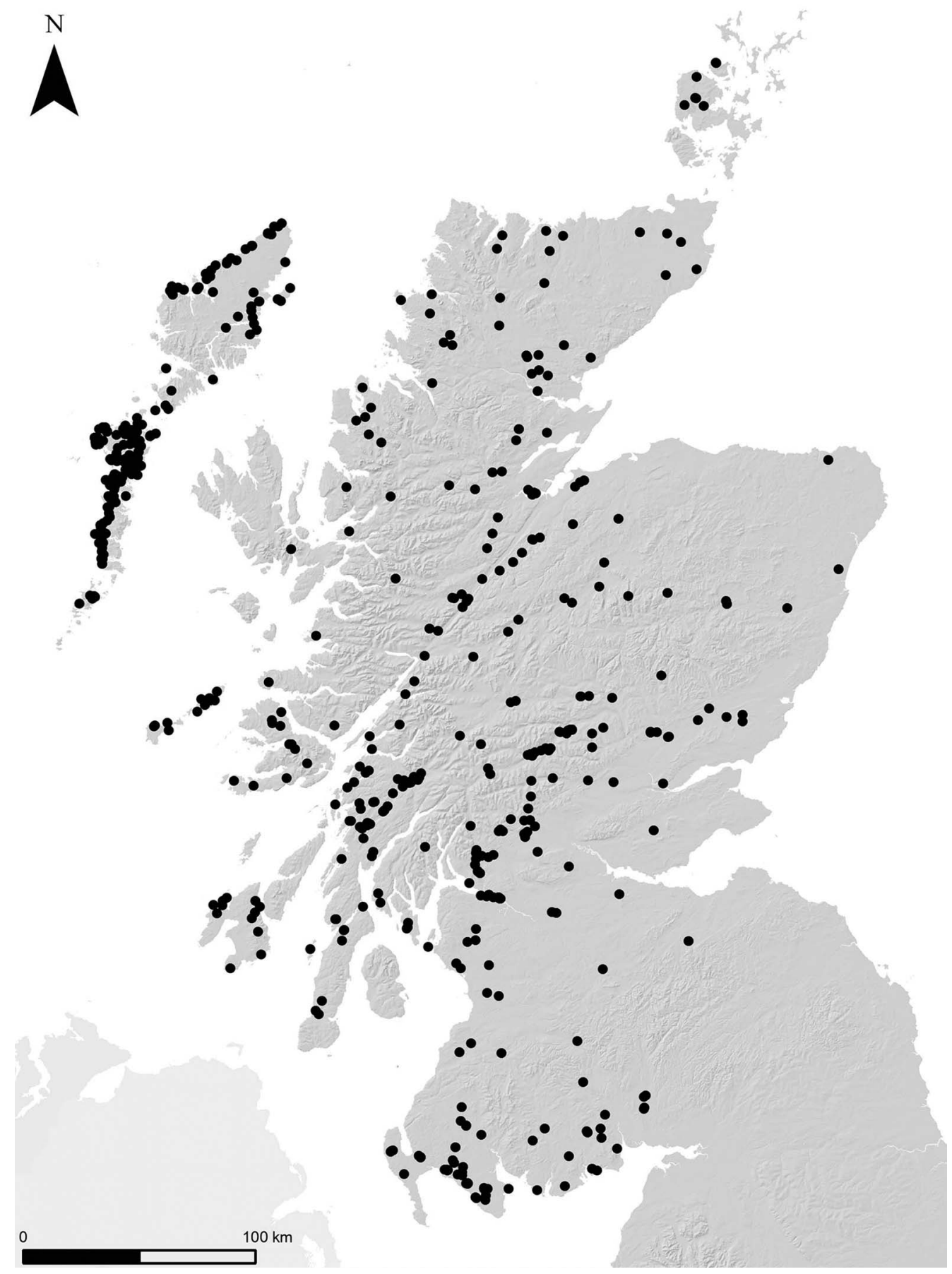

Figure 1. Distribution of island dwellings (including 'crannogs' and 'island duns') in Scotland (data from Lenfert 2012: Appendix 1). Contains OS data (C) Crown copyright and database right 2019. 
125-27). The Outer Hebrides represent a particular hotspot in their distribution with over 170 known sites (Lenfert 2012). It is estimated that as many as 2000 crannogs were built across Ireland, and a single example is known also in Wales (Redknap \& Lane 1994; Fredengren 2002: 6). The general academic consensus is that Scottish crannogs were built, used and re-used over a period of 2500 years from the Iron Age to the post-medieval period, c. $800 \mathrm{BC}$ to AD 1700 (Crone 2012).

It was only due to extensive radiocarbon dating programmes during the 1970-1990s that the later prehistoric elements of many sites in Scotland were fully recognised (Crone 1993; Henderson 1998). Excavation of Eilean Domhnuill, North Uist, in the 1980s revealed that this artificial islet site was built and used in the Neolithic period (Armit 2003). Consequently, many writers speculated that such islets may have been constructed more widely during the Neolithic, $c$. 4000-2400 BC (e.g. Crone 1993: 248; Henderson 1998: 229; Cavers 2010: 42). Until the work outlined here, however, no further sites of this date had been found. This article presents the results of recent survey and excavation that demonstrate conclusively — and for the first time - the widespread presence of Neolithic crannogs in the Outer Hebrides.

Archaeologists have long debated exactly how a 'crannog' should be defined and it has proven difficult to reach a consensus (e.g. Morrison 1985; Henderson 1998; Dixon 2004; Cavers 2012). As Henderson and Sands (2012: 269) point out, 'crannog' is generally used as "a portmanteau term" to refer to all forms of artificial islets found in Scotland and Ireland. Although this wide applicability is convenient, it should be emphasised that the shared characteristics of these islets (at a very general level) do not necessarily mean that all crannogs were part of single tradition, or that we should seek the origins of later sites in the earliest examples in a given region (Henderson $\&$ Sands 2012). This article focuses on a set of newly discovered Neolithic crannogs in the Outer Hebrides. These sites may have fulfilled a function quite different to those built in later periods; equally, on present evidence, there appears to have been a significant gap in artificial islet construction during the Late Neolithic/Bronze Age (c. 3000-800 BC). Any interpretive links between the sites described here and later crannogs should therefore be made with caution. Nevertheless, given the very high density of crannogs of all dates in the Outer Hebrides, it is important to establish a long-term narrative of islet construction there, in order to explore their earliest origins and investigate their functions and meanings.

As detailed below, these newly discovered sites are important for several reasons. The human activities in evidence at, and the physical character of, the islets also force us to reconsider the nature of Neolithic settlement and monumentality on a much broader scale. Further, the acts of watery deposition evidenced at these islets represent a previously unrecognised practice during this period. This article also considers the possibility that Neolithic crannogs may be found beyond the Outer Hebrides as well.

\section{Neolithic crannogs}

The notion that crannogs could date to as early as the Neolithic period first arose following Armit's 1980s excavations at Eilean Domhnuill (Armit 2003; Copper \& Armit 2018). Soon after commencing excavation, Armit and his team encountered substantial quantities of Neolithic pottery on what was expected to be an Iron Age islet. Several seasons of excavation

(C) Antiquity Publications Ltd, 2019 
revealed 11 phases of Neolithic archaeology, with the site's occupation dated from $c .3720$ 3510 to $c .2600$ cal BC (at 95 per cent confidence) (the latter phases of the site are currently not well defined chronologically; Garrow et al. 2017a: 115; see also Copper \& Armit 2018). The best-preserved layers contained stone walls, stone-built hearths, postholes and spreads of occupation debris including 22000 sherds of pottery.

Following the recognition of Eilean Domhnuill's early origins, numerous writers suggested that further discoveries of Neolithic crannogs were likely. Nonetheless, despite sustained surveys (e.g. Dixon \& Topping 1986; Henley 2012; Lenfert 2012), no such sites were found. Two previously excavated sites that had yielded Neolithic material cultureEilean an Tighe, North Uist, and Pygmie's Isle, Lewis—are questionable, as doubt remains as to whether or not they were islets during the Neolithic (Scott 1951: 2; Lenfert 2012: 219), and neither was artificially constructed.

The situation regarding recognition of Neolithic crannogs changed dramatically in 2012. Chris Murray, a resident of Lewis and former Royal Navy diver, was sufficiently intrigued by one islet that he decided to dive around it. His discovery of a series of remarkably wellpreserved Early/Middle Neolithic 'Hebridean Neolithic' and 'Unstan' pots lying on the loch bed was completely unexpected. Following this discovery, Murray and the then conservation officer at Museum nan Eilean, Stornoway, Mark Elliott, embarked on a sustained search of other accessible islet sites_identified using Google Earth—across Lewis. In several cases, they found similarly impressive assemblages of Neolithic pottery (Figure $2 \&$ Table 1). The presence of Neolithic crannogs beyond Eilean Domhnuill had, at last, apparently been confirmed (Figure 3; Sheridan et al. 2014). It is worth noting that two of the five Neolithic sites identified were not recorded within the National Record of the Historic Environment or Historic Environment Record; the other three were assumed to be later in origin, and none had been radiocarbon dated.

\section{The Neolithic of the Outer Hebrides}

The Early/Middle Neolithic of the Outer Hebrides is renowned both for its tombs and settlements (Figure 4; see Garrow \& Sturt 2017: 19-22). The tombs fall into two main groups: passage graves and Clyde cairns (Henshall 1972). The dearth of modern excavations of tombs and the consequent absence of radiocarbon dates means that the chronological relationship between these two different tomb types and their position within the span of the Neolithic remain unclear (Armit 1996: 76; Henley 2003: 168; Garrow et al. 2017a). Notably, the distribution of tombs across the Outer Hebrides is irregular, with a higher density in North Uist (Figure 4). Consequently, some scholars have suggested that there may have been a surge in social competition due to pressure on land (Sharples 1992: 327; Armit 1996: 76).

In contrast to the investigation of tombs, almost all the settlement excavations are relatively recent. The impressive architecture and material culture assemblages at Eilean Domhnuill, described above, are echoed to a lesser extent at several other sites. Eilean an Tighe, The Udal, An Doirlinn and Allt Chrisal, for example, have all produced multiple phases of occupation, low stone walls, large hearths, postholes and spreads of occupation debris. Other Neolithic settlement sites are represented by more ephemeral archaeology, such as small-scale middens, pits and postholes (see Garrow \& Sturt 2017: 19-22). Several scholars have emphasised the

(C) Antiquity Publications Ltd, 2019 


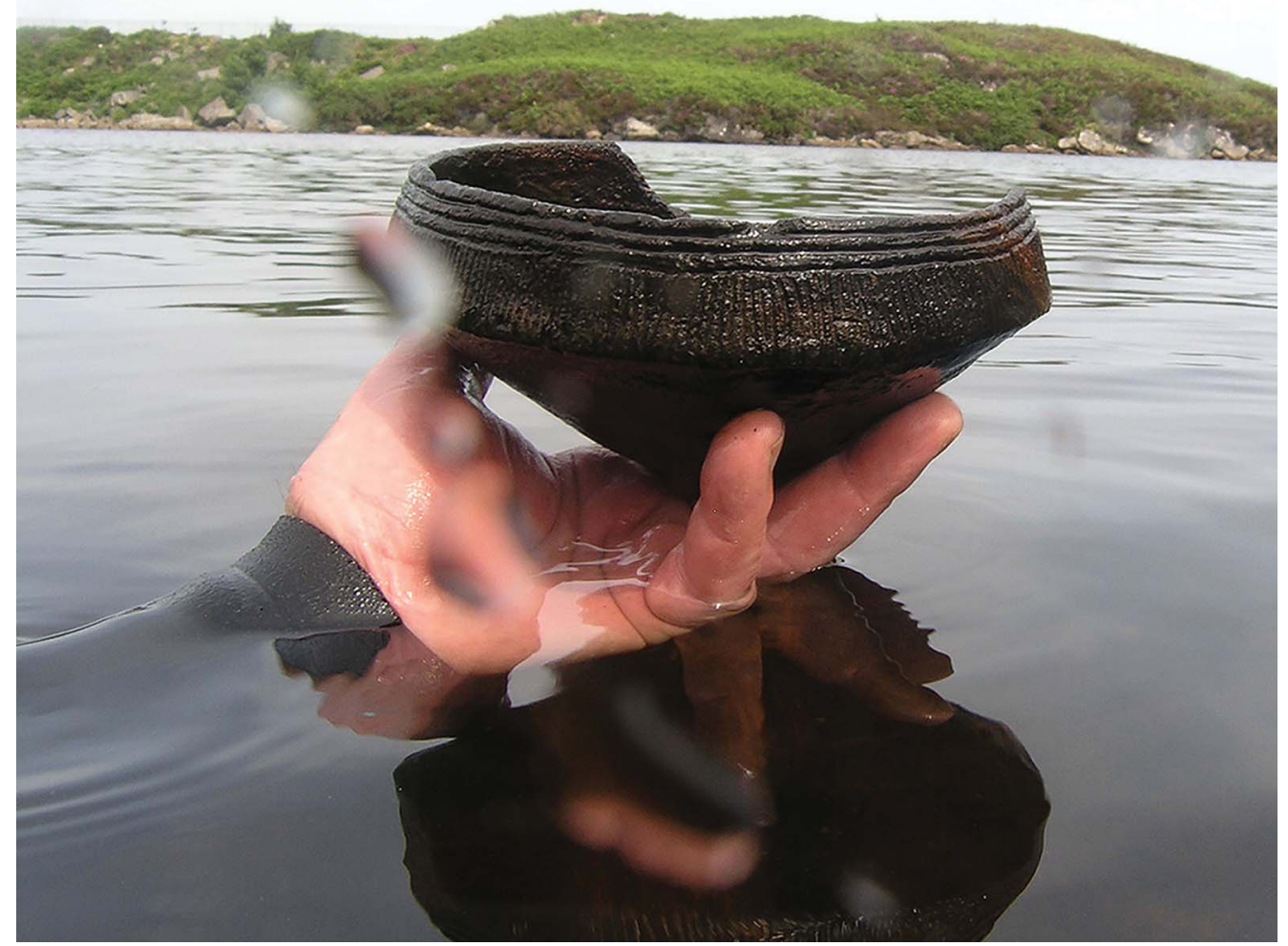

Figure 2. Recovering an Unstan vessel from Loch Arnish in 2012 (photograph by C. Murray).

Table 1. Neolithic vessels recovered from islet sites on the Isle of Lewis since 2012.

Site

Vessels (no.)

Loch Arnish 58

Loch Bhorgastail 59

Lochan Duna (Ranish)

Loch an Dunain (Carloway)

Loch Langabhat

differential distribution of Neolithic settlements when attempting to understand contemporaneous social dynamics. Armit (1996) has suggested that architectural differences between sites may have been related to settlement function, with some occupied all year round and others only seasonally. Similarly, Henley (2003: 133) and Copper and Armit (2018) have observed that apparently contemporaneous sites produce very different ceramic assemblages, and that differences in social status and identity may explain this divergence in material culture. 
Neolithic crannogs: settlement, monumentality and deposition in the Outer Hebrides

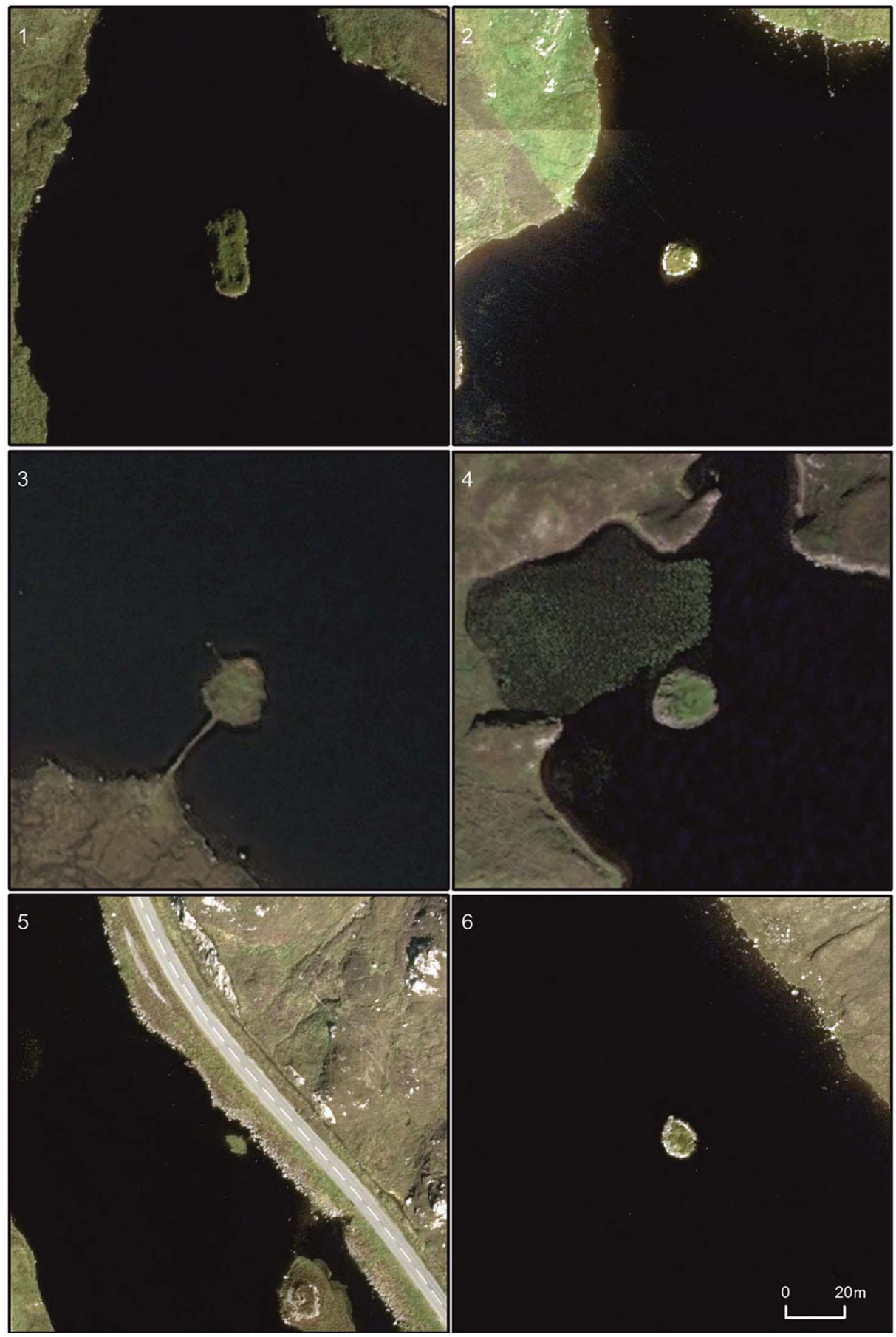

Figure 3. Aerial photographic comparison of the six islet sites known to have produced Neolithic material (all shown at the same scale): 1) Arnish; 2) Bhorgastail; 3) Eilean Domhnuill; 4) Lochan Duna (Ranish); 5) Loch an Dunain (Carloway); 6) Langabhat (images (C) of Getmapping PLC). 

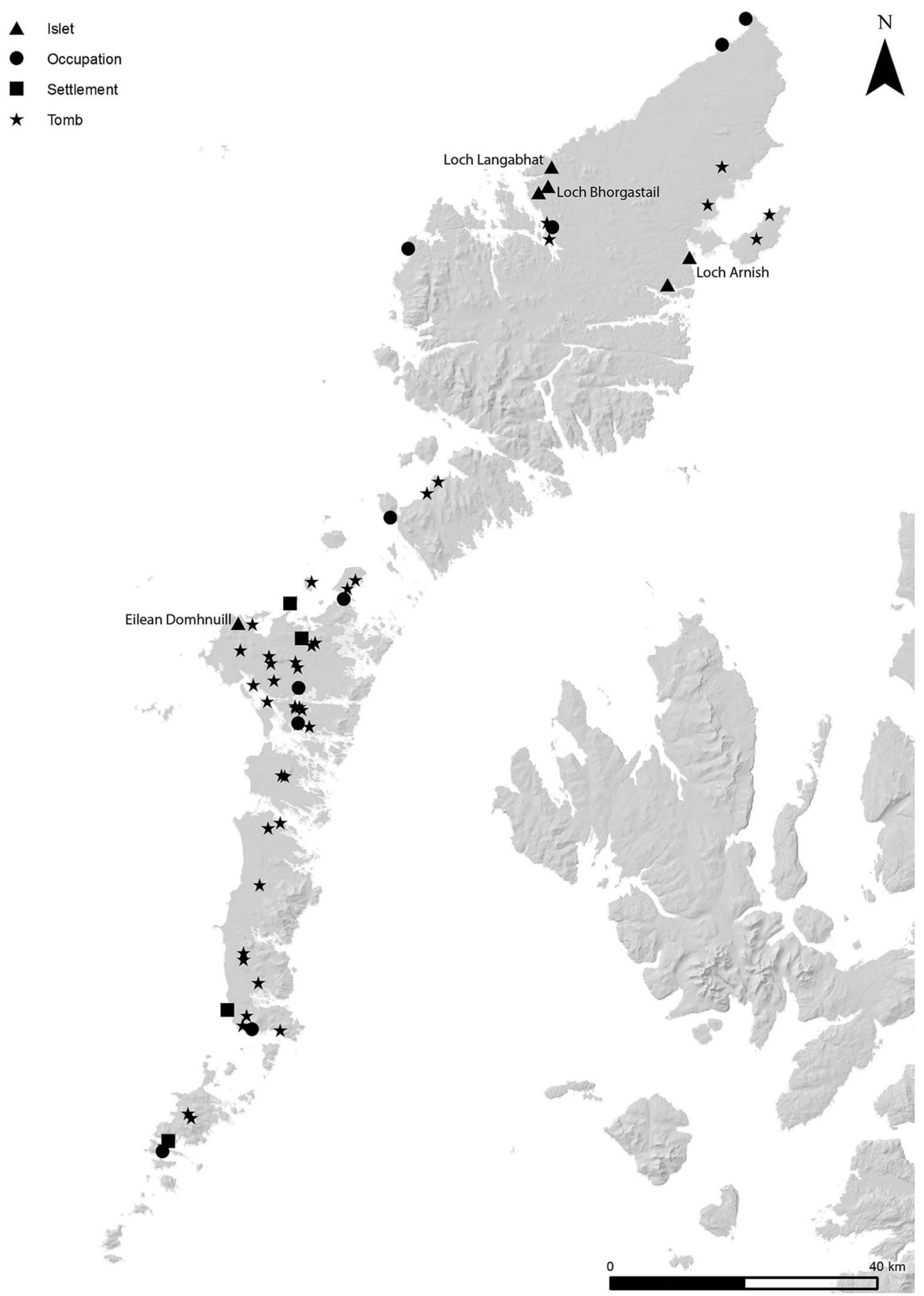

Figure 4. Distribution of known Early/Middle Neolithic tombs, 'settlements' (with buildings), 'occupation sites' (more ephemeral traces of settlement) and islet sites in the Outer Hebrides, with key sites labelled (data from Canmore.org.uk and Garrow \& Sturt 2017). Contains OS data (C) Crown copyright and database right 2019.

(C) Antiquity Publications Ltd, 2019 
Due to their recent discovery, the unusual crannog sites considered here have not yet been incorporated into broader discussions of the region. As discussed later, these sites have the potential to transform existing narratives.

\section{Exploring Neolithic crannogs on the Isle of Lewis}

Following Murray's discoveries - and in collaboration with him from the outset-our investigations in 2016-2017 were designed to understand the characteristics of the islets, the context of the material found in the lochs around them, and the broader topographic and social landscape within which they were constructed. Given the limited time available, it was not possible to explore all five sites known to have produced Neolithic material (Table 1). Consequently, our preliminary survey focused on three sites: Loch Arnish, Loch Bhorgastail and Loch Langabhat. Our subsequent, more detailed survey focused on Bhorgastail and Langabhat (Figure 5), with only the latter subject to excavation. The techniques applied include side-scan sonar, dualfrequency single-beam echo-sounder, underwater diver surveys, underwater and aerial photogrammetry, real-time kinematic GPS survey, palaeoenvironmental coring and terrestrial excavation. The methods employed and full results are provided in interim reports published for each season's work (Garrow et al. 2017b; Garrow \& Sturt 2019). The project's aims were:

- To determine the local topographic context of the islets.

- To establish whether the islets were artificially constructed and to record in detail their architectural form.

- To ascertain the presence of any features, or other archaeological evidence, atop or around the islets.

- To plot the distribution of, and recover further material from, the loch beds.

- To obtain samples suitable for radiocarbon dating.

At Bhorgastail, we removed surface vegetation across the full width (12m above the water) of the islet, in a $2 \mathrm{~m}$-wide strip. At Langabhat, we conducted more substantial excavations, digging an initial $2 \mathrm{~m}$-wide trench across the islet. This was subsequently extended in order to explore a small oval structure and other occupation deposits.

\section{Architecture and local topographic context}

Bathymetric survey indicates that both the Bhorgastail and Langabhat islets are located on local rises in the loch bed, adjacent to areas of deeper water (Figure 6). Both are clearly human-made, created through the piling up of boulders on the loch bed to form artificial islets (Figures 7-8). The evidence from these sites suggests that loch levels were probably similar at the time of construction in the Neolithic to those of today. The clastic sequences revealed in exposed sections and through coring indicate that these islets were probably surrounded by shallow water on three 'sides', with deeper water on the fourth.

At Langabhat, the islet builders made use of an existing natural crag that rises above the water's surface. Rocks were piled around this, creating a shallow, volcano-like form, the 'crater' of which was infilled with rocks to create a flattish surface (Figures 7-9). In the absence of

(C) Antiquity Publications Ltd, 2019 


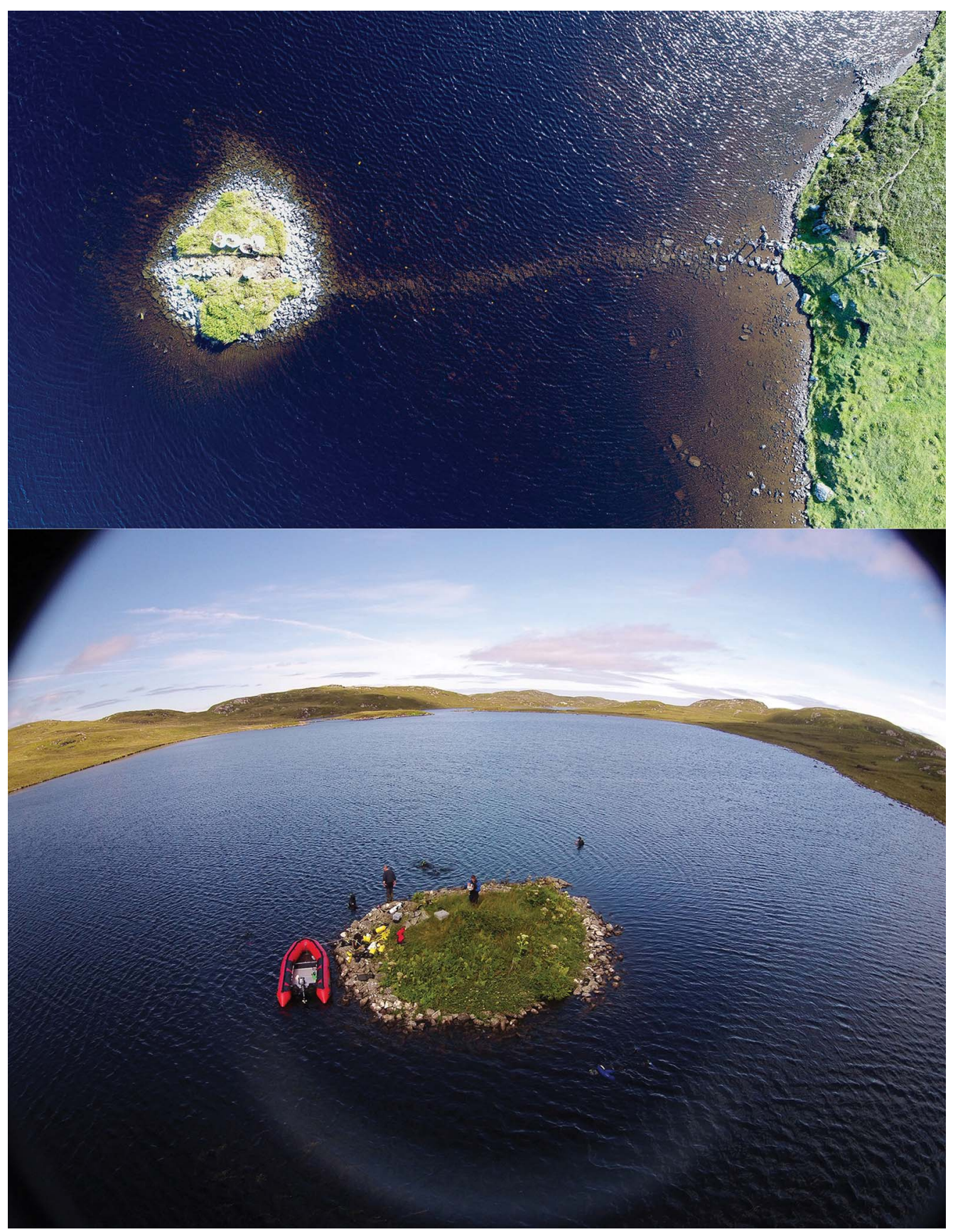

Figure 5. Aerial views of the islets in Loch Bhorgastail (top) and Loch Langabhat (bottom) (photographs by F. Sturt). a natural crag, the Bhorgastail islet was constructed entirely artificially. It nonetheless had a similar volcano-like form, infilled to create a flattish central space (Figures 7-8). Although Bhorgastail was not excavated, organic rich 'peaty' deposits were observed in its centre. This contrasts with Langabhat, which was stony throughout. Notably, at Bhorgastail, (C) Antiquity Publications Ltd, 2019 
Neolithic crannogs: settlement, monumentality and deposition in the Outer Hebrides
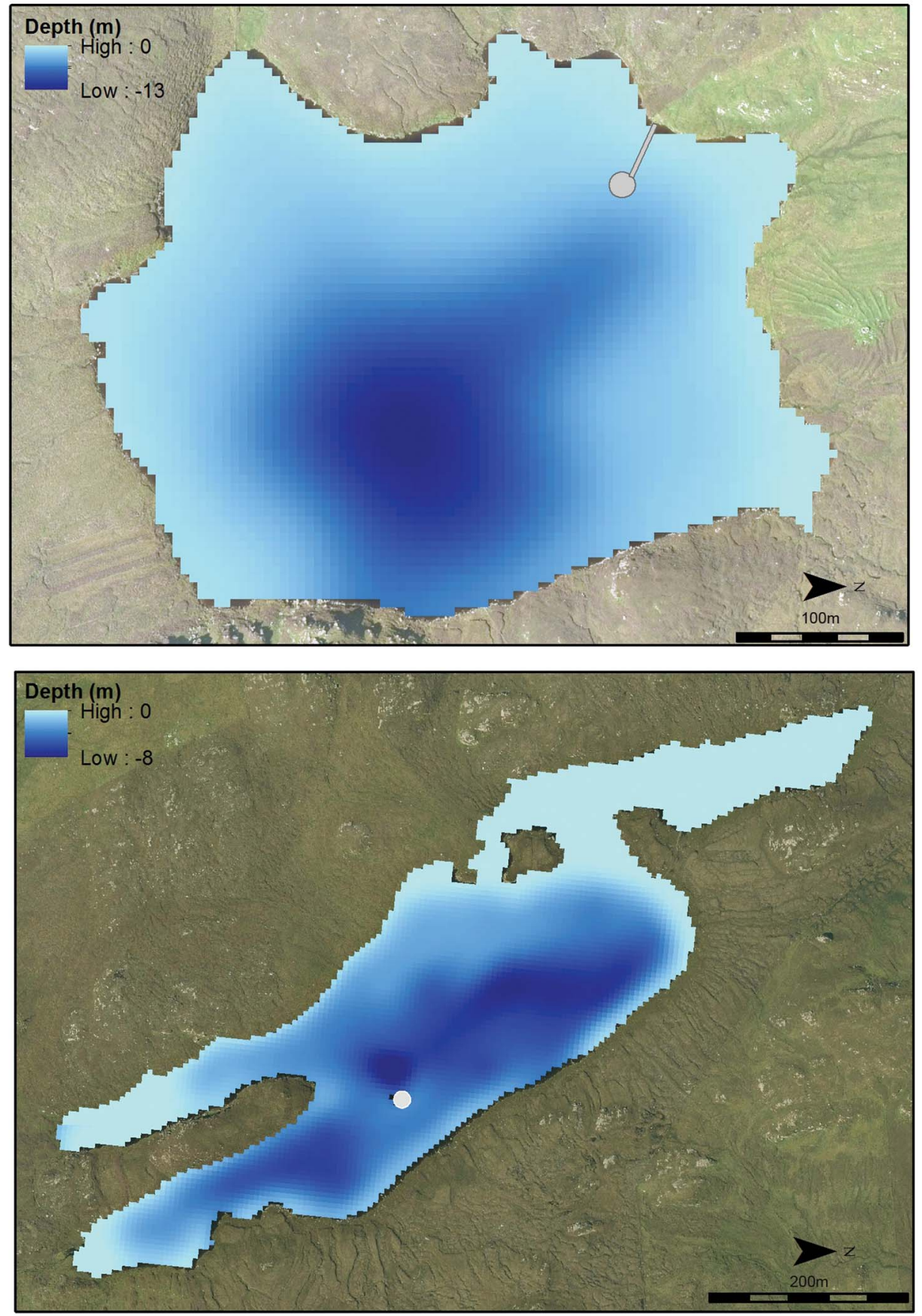

Figure 6. Bathymetric models for Loch Bhorgastail (top) and Loch Langabhat (bottom) (aerial imagery () Getmapping PLC; figure by F. Sturt). 

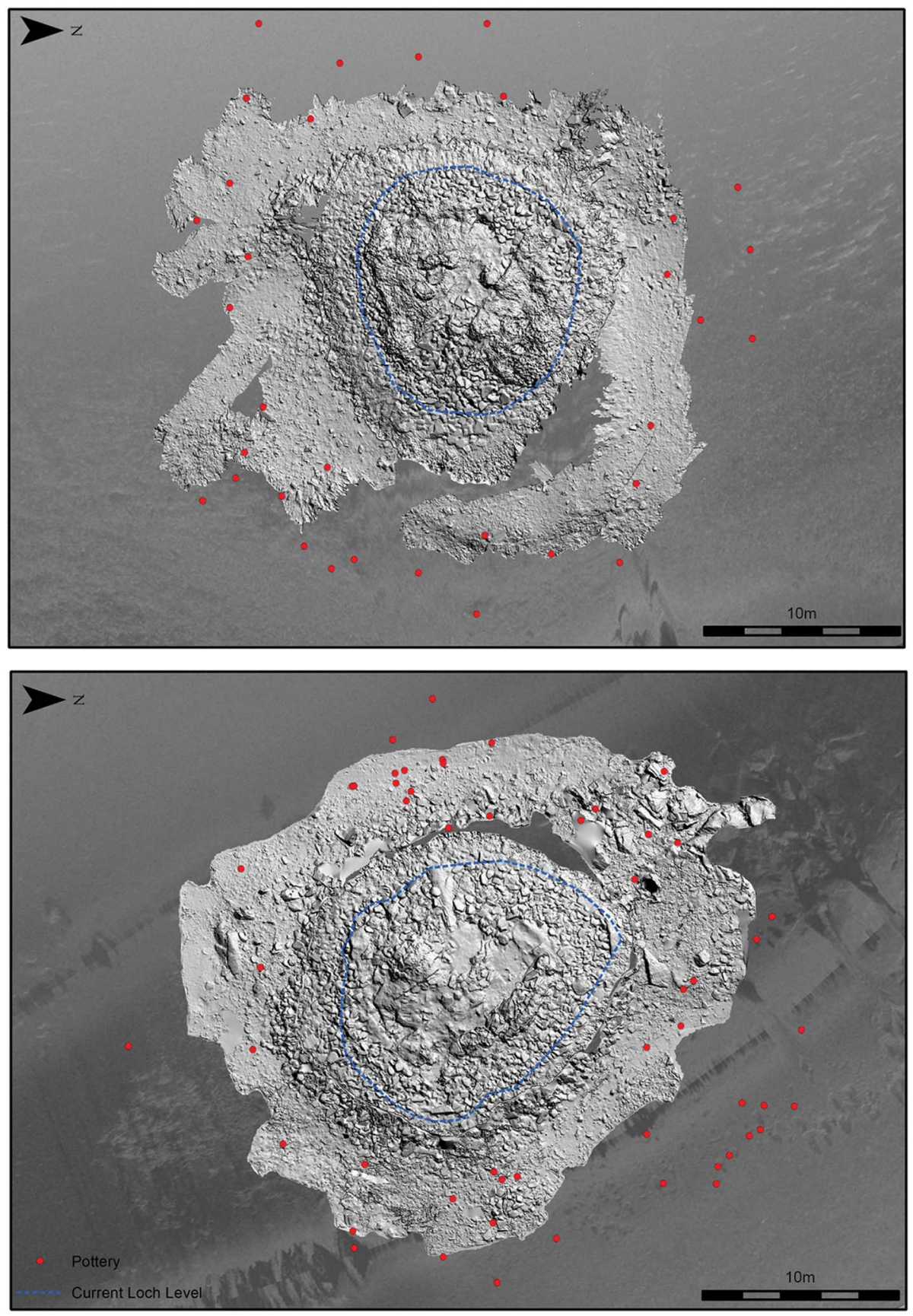

Figure 7. The islets at Loch Bhorgastail (top) and Loch Langabhat (bottom), with pottery findspots (red dots) and current loch levels (blue dashes) indicated: multi-directional hillshade of digital elevation model from photogrammetry (3mm resolution) overlying side-scan sonar (10mm resolution) (figure by F. Sturt).

(C) Antiquity Publications Ltd, 2019 

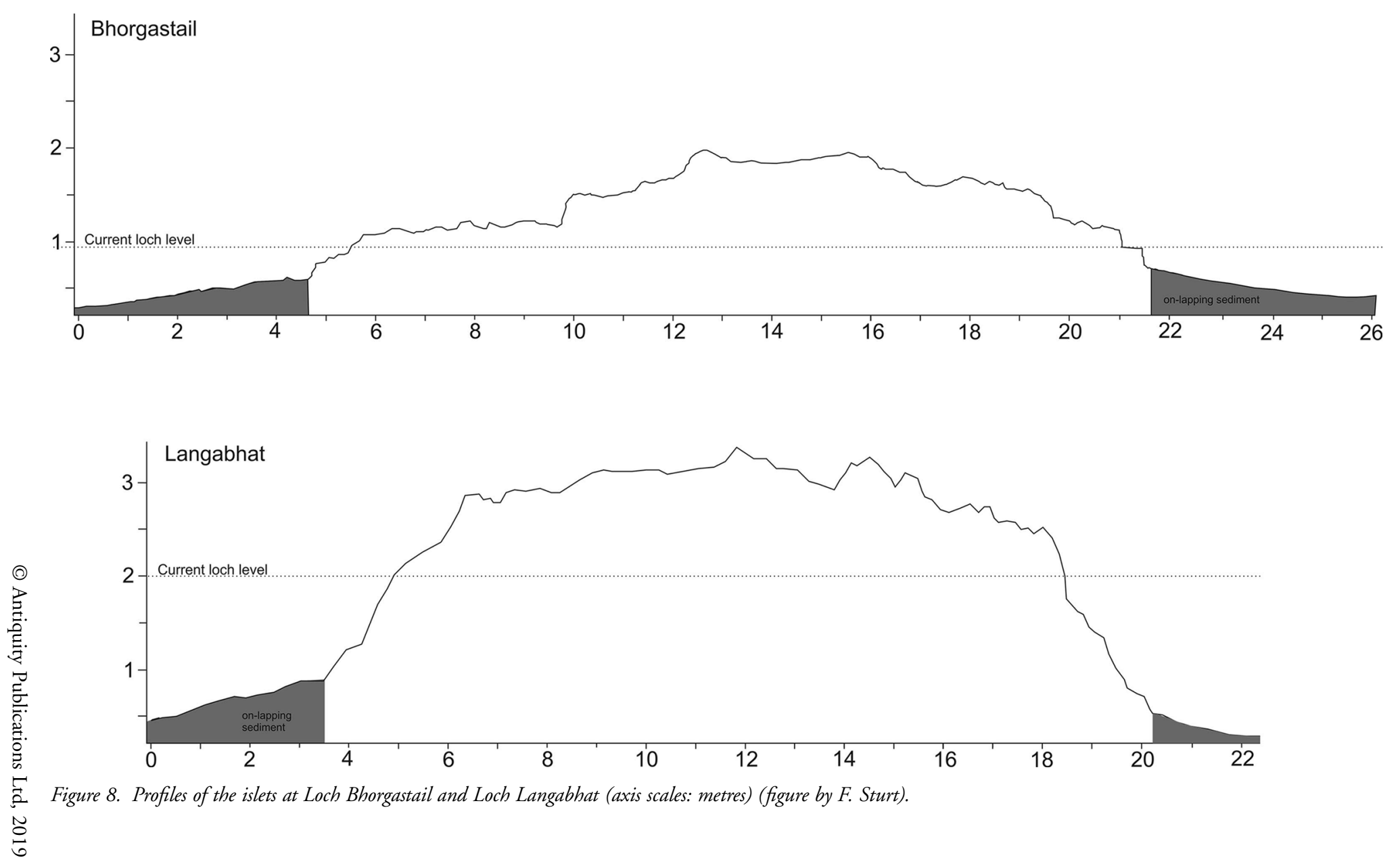

Research 


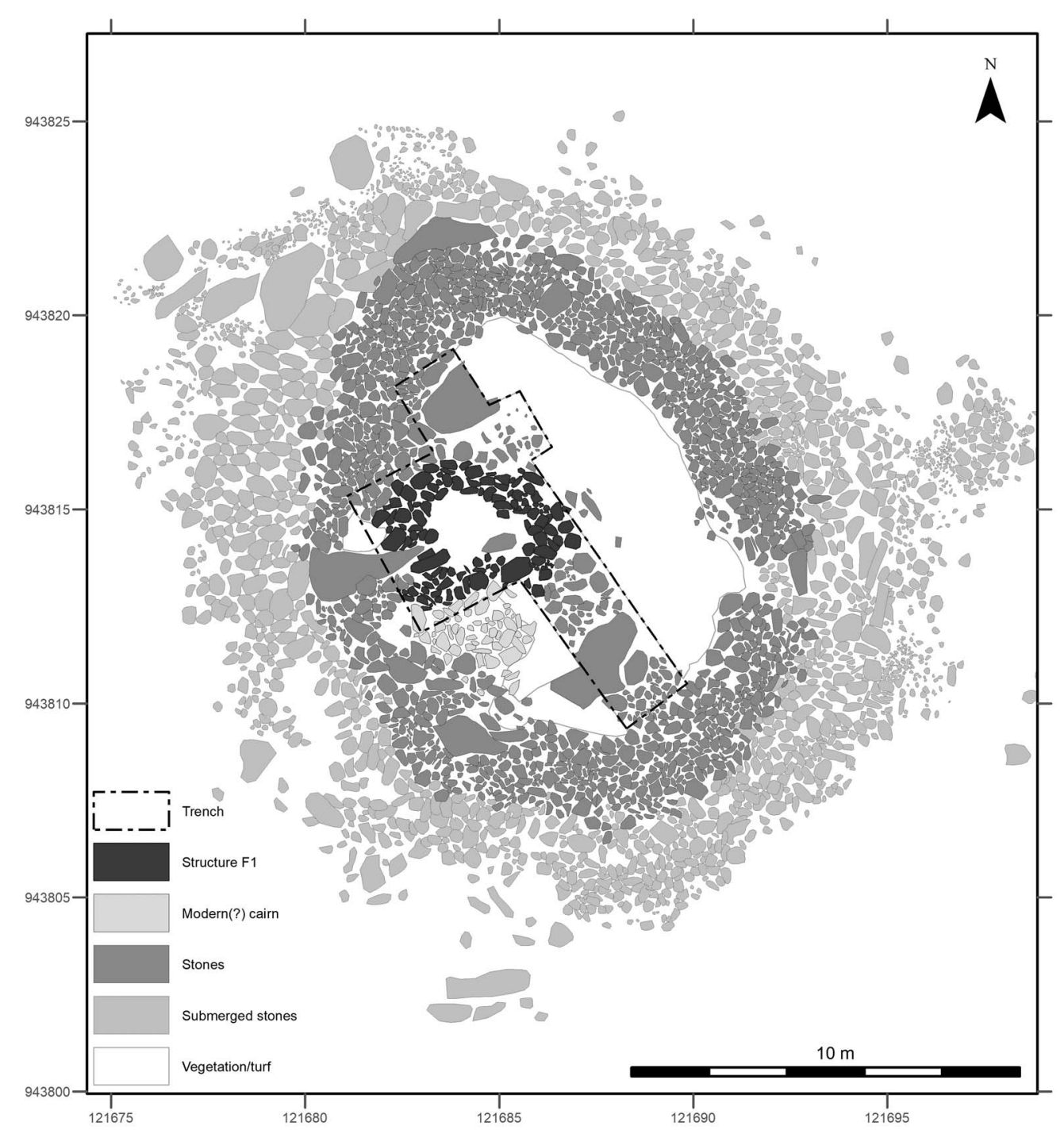

Figure 9. Plan of 2017 excavations at Loch Langabhat (figure by D. Garrow \& F. Sturt).

numerous worked timbers were observed underwater, towards the edges of the islet. Posts were sunk vertically through the silts and clays of the loch bed, with horizontal timbers fixed between them. These appear to be revetting constructed to stabilise the structure at the location where the islet's natural shelf gives way to deeper water.

The two islets represent very substantial constructions. The islet at Bhorgastail measures approximately $26 \times 22 \mathrm{~m}$, and Langabhat $19 \times 17 \mathrm{~m}$ (representing the complete artificial structures, including those parts below the water surface) (Figure 7). The rocks that comprise both islets measure up to $0.7 \times 0.4 \times 0.3 \mathrm{~m}$ in size, weighing up to $250 \mathrm{~kg}$ each. At Bhorgastail, a stone causeway was built leading from the west of the islet towards the closest shoreline (Figure 5). No such causeway has yet been detected at Langabhat; it is possible that the (C) Antiquity Publications Ltd, 2019 
islet was accessed by boat or a wooden causeway, although no evidence for either has so far been discovered.

On the islets themselves, no clear evidence of any Neolithic structures has yet been identified. On both sites, the presence of apparently modern, small cairns suggests that later activity may have disturbed original features. At Langabhat, a small, oval stone structure $(3 \times$ $1.5 \mathrm{~m}$ ) was identified just west of the islet's central point (Figure 9). In places, the structure's dry stone walling survives five courses high. Dark, charcoal-rich occupation deposits were identified within, yielding limited quantities of worked lithics and small sherds of Neolithic pottery. Hence, during the excavation, we assumed that this structure was Neolithic. Two radiocarbon dates, however, indicate that it was actually used - and therefore probably (if not certainly) constructed-in the Middle Bronze Age, c. 1420-1130 cal BC. Samples were taken from two separate layers, one of which was situated immediately above the stone 'floor' of the structure and so can be considered to be associated with its primary occupation; the Neolithic finds within these deposits could be residual. The Middle Bronze Age activity, which relates to a period not usually associated with crannog occupation (Lenfert 2013: 130-31), was not clearly suggested by any diagnostic material culture; radiocarbon dating reminds us that other incidences of re-use at these sites may not have left much, or indeed any, immediately dateable imprint.

\section{Material recovered from the loch bed}

The recovery of multiple ceramic vessels from the loch beds surrounding the islets provided the first indication of the sites' Neolithic origins. Our work has subsequently confirmed and elucidated this pattern of substantial material deposition into the water. In total, parts of 59 different vessels have been recovered from the loch at Bhorgastail, and 73 from Langabhat (Figure 7).

At Langabhat, the quantities and condition of ceramics recovered from the loch and from surface excavations are completely different. While some pottery was deposited on the islet itself during its Neolithic occupation and use, the vast majority ended up in the water around it (Figures $7 \& 10$ ). The material recovered from the islet was generally abraded and fragmentary, whereas that from the loch is in very good condition and is substantially more complete (Table 2). The low-energy nature of the loch sediments—-revealed by coring and diver survey, and supported by the slow sedimentation rates identified in lochs across the region (Lomax 1997: 144; Edwards \& Whittington 2001: 163)—suggests that the loch bed ceramics are unlikely to have been transported over any significant distance. They were almost certainly deposited directly into the water surrounding the islet.

The quantities of material now identified around several sites, and the position of these vessels in relation to the islets, suggests that pots were intentionally deposited into the water. Many vessels had substantial sooting on their external surfaces, and some had internal charred residues; they had clearly been used before deposition. The large fragment sizes of these vessels suggest that at least some, and possibly all, of the vessels were complete when they entered the water. 


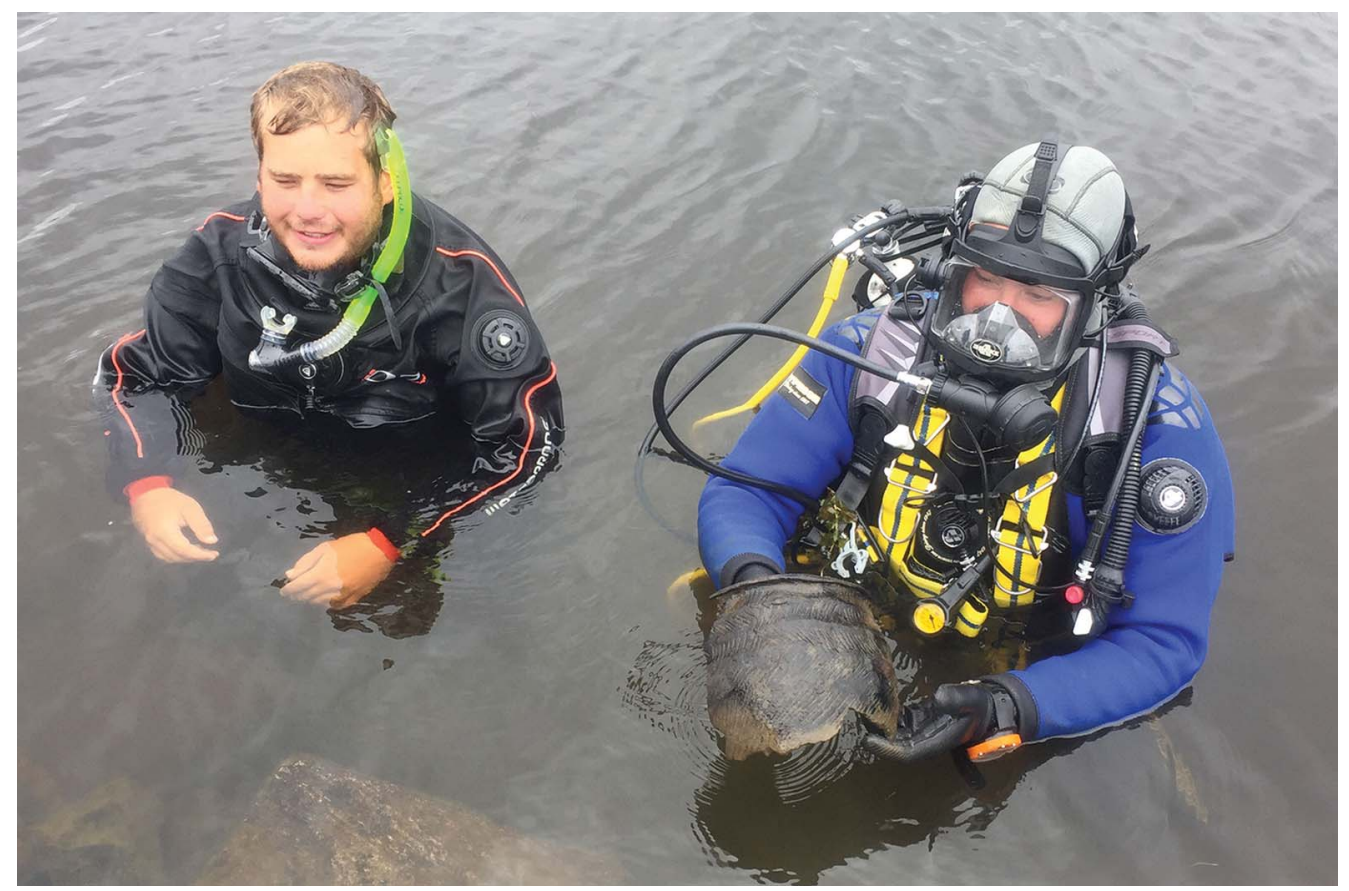

Figure 10. Recovering a substantial fragment of a 'Hebridean Neolithic' vessel from Loch Langabhat in 2017 (photograph by D. Garrow).

Table 2. Comparison of pottery assemblages recovered from the surface of the islet and the loch bed at Langabhat.

\begin{tabular}{lcccc}
\hline & Sherds (no.) & Weight (g) & No. vessels (estimated) & Mean sherd weight (g) \\
\hline Islet surface & 12 & 234 & 10 & 19.5 \\
Loch bed & 97 & 8430 & 73 & 86.9 \\
\hline
\end{tabular}

\section{Radiocarbon dating}

Eight radiocarbon determinations have been obtained from four islet sites across Lewis (Table 3). The six that fall within the Neolithic are quite closely grouped, ranging from $c$. 3640-3360 cal BC. The fact that the dates were obtained from worked structural timbers associated with Bhorgastail's construction and from pot residues associated with the four sites' use potentially suggests a narrow window of occupation or use for all of them. Further dating, however, is required to refine this picture.

\section{Summary}

It is now clear that these sites are artificially constructed Neolithic islets, or crannogs. They were created by piling up rocks onto the loch bed, sometimes making use of existing natural (C) Antiquity Publications Ltd, 2019 
Table 3. Radiocarbon dates from Neolithic islet sites in Lewis. Radiocarbon ages calibrated to the calendar timescale using OxCal 4.3.2 (Bronk Ramsey 2018). Date ranges calibrated using the IntCal13 atmospheric calibration curve (Reimer et al. 2013). Note that OxA-coded dates were previously published in Garrow et al. (2017a).

\begin{tabular}{|c|c|c|c|c|c|c|c|c|}
\hline & Lab code & Site name & Material & Species/type & Context & $\begin{array}{l}\text { Radiocarbon } \\
\text { age }\end{array}$ & $\begin{array}{l}\delta 13 \mathrm{C}(\% 0) \\
(\text { error } \pm 0.2 \\
\text { per mille })\end{array}$ & $\begin{array}{c}\text { Calibrated } \\
\text { date range (cal } \\
\text { BC) at } 95 \% \\
\text { confidence }\end{array}$ \\
\hline & OxA-28953 & Loch Arnish & Charred residue & $\begin{array}{l}\text { Internal food residue on } \\
\text { 'Hebridean' vessel }\end{array}$ & $\begin{array}{l}\text { Unstratified: loch } \\
\text { bed }\end{array}$ & $4620 \pm 30$ & -26.3 & $3510-3350$ \\
\hline & OxA-28955 & $\begin{array}{l}\text { Lochan Duna } \\
\text { (Ranish) }\end{array}$ & Charred residue & $\begin{array}{l}\text { Internal food residue on } \\
\text { 'Hebridean' vessel }\end{array}$ & $\begin{array}{l}\text { Unstratified: loch } \\
\text { bed }\end{array}$ & $4658 \pm 30$ & -26.3 & $3520-3370$ \\
\hline & OxA-28954 & Loch Bhorgastail & Charred residue & $\begin{array}{l}\text { Internal food residue on } \\
\text { 'Hebridean' vessel }\end{array}$ & $\begin{array}{l}\text { Unstratified: loch } \\
\text { bed }\end{array}$ & $4749 \pm 30$ & -21.6 & $3640-3380$ \\
\hline & SUERC-77427 & Loch Bhorgastail & Wood & Salix sp.-outer rings & $\begin{array}{l}\text { [30]: worked timbers } \\
\text { east of islet }\end{array}$ & $4737 \pm 24$ & -27.3 & $3630-3380$ \\
\hline & SUERC-77428 & Loch Bhorgastail & Wood & Salix sp.-outer rings & $\begin{array}{l}\text { [31]: worked timbers } \\
\text { east of islet }\end{array}$ & $4629 \pm 23$ & -27.4 & $3500-3360$ \\
\hline (a) & SUERC-77434 & Loch Langabhat & Charred residue & $\begin{array}{l}\text { Internal food residue on } \\
\text { 'Hebridean' vessel }\end{array}$ & $\begin{array}{l}\text { Unstratified: loch } \\
\text { bed, findspot [8] }\end{array}$ & $4708 \pm 25$ & -26.4 & $3630-3380$ \\
\hline 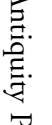 & SUERC-77432 & Loch Langabhat & Wood charcoal & $\begin{array}{l}\text { Alnus cf glut- } \\
\text { small-medium } \\
\text { branch }\end{array}$ & $\begin{array}{l}\text { [52]: occupation } \\
\text { deposits inside } \\
\text { structure F1 }\end{array}$ & $3089 \pm 24$ & -25.4 & $1420-1290$ \\
\hline 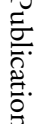 & SUERC-77433 & Loch Langabhat & Wood charcoal & $\begin{array}{l}\text { Alnus cf glut-medium } \\
\text { branch }\end{array}$ & $\begin{array}{l}\text { [57]: occupation } \\
\text { deposits inside } \\
\text { structure F1 }\end{array}$ & $2996 \pm 24$ & -26.2 & $1370-1130$ \\
\hline
\end{tabular}

\section{Research}


features. The overall architecture of the islets was designed to create a flattish central area approximately $10 \mathrm{~m}$ across. Although no Neolithic structures have been identified, only one site has so far been excavated. Whatever the function of these sites, the most apparent archaeological evidence is the presence of large numbers of pots deposited into the water around the islets.

\section{Discussion}

Settlement, monumentality and deposition in the Neolithic

It is now apparent that islet construction was a widespread practice in the Outer Hebrides during the Neolithic. The possibility of an early date for crannog construction, first raised by the excavation of Eilean Domhnuill, has now been realised-in Lewis at least. Nonetheless, despite this confirmation of previous suspicions, there are clear differences between Eilean Domhnuill and those sites that we have reported here. The former was a much larger islet than either Bhorgastail or Langabhat. It also produced clear evidence for Neolithic stone structures right from the latest levels; no such evidence has been forthcoming from our sites. Excavation at Eilean Domhnuill produced an assemblage of 22000 ceramic sherds; by contrast, Langabhat yielded 12 sherds. As at other Lewis sites, however, many large fragments were recovered from the loch around Langabhat islet-a pattern of deposition as yet not recognised at Eilean Domhnuill, although the loch bed there was not thoroughly investigated (Dixon 1989). Hence, Eilean Domhnuill and Langabhat are not directly comparable sites, and Neolithic artificial islets in the Outer Hebrides appear to have been neither used nor perceived in a uniform way.

In order to approach a broadly contextualised interpretation of our sites, it is helpful to revisit some earlier discussions of Eilean Domhnuill. Armit has suggested, for example, that it may have been a place of special significance in the landscape, albeit one of impermanent occupation:

its permanence, its monumentality, its peculiar location, and the repeated renewal of its buildings, combine to suggest that it played a pivotal role in the cultural landscape of Neolithic North Uist comparable with the role played by the better-known funerary monuments (Armit 2003: 99).

Cummings and Richards (2013: 198-200) compared travelling to Eilean Domhnuill on a causeway across the water with the journey along the tunnel-like passageways of contemporaneous passage grave tombs; others have commented on the site's isolation and 'liminal' location (Henley 2003: 137; Cummings \& Richards 2013). Most recently, Copper and Armit (2018) — now aware of the newly discovered Lewis islet sites—have suggested that they could have been special places associated with social gatherings, ritualised feasting and commensality.

The Lewis islet sites certainly have a monumentality of their own that is comparable with contemporaneous passage graves. They would have required a huge investment of labour to build and probably remained significant places for a long time. Such islets may well have represented substantial symbols for, and of, the communities that constructed them. These islets (C) Antiquity Publications Ltd, 2019 
could also have been perceived as special places, their watery surroundings creating separation from everyday life. The process of crossing over to the islets may have emphasised this separation; the practices that took place on them do appear to have been very different from those of 'normal' life. These may have included feasting, involving the pots that were subsequently deposited into the surrounding water. The activities that occurred on these islets could have resembled those that happened at tombs elsewhere across the Outer Hebrides. It is even conceivable that the islets were themselves associated with mortuary practices, the evidence for which is so far rendered invisible by watery deposition and the acidic local soils.

The Lewis islets, therefore, may be viewed as falling somewhere in between tombs and settlements, in relation both to their architecture and to the practices associated with them. The position of the islets within their broader contemporaneous landscape has implications for the overarching narratives that we currently construct about the Neolithic-in both the Outer Hebrides and more widely across Britain, and beyond. Perhaps most notably, these sites remind us to question the binary opposition sometimes assumed between Neolithic 'settlement' and 'monuments'. In the Outer Hebridean Neolithic, 'settlements' were not a uniform category of site. They comprised different architectures, were situated in varied landscape locations and were associated with sometimes extremely different assemblages and, undoubtedly, different practices (Garrow \& Sturt 2017: 19-22). It is possible that tombs were equally varied in their character. Indeed, many writers have commented on the variable architectures of Neolithic monuments in the region (Henshall 1972; Armit 1996; Cummings \& Richards 2013); too few, however, have been excavated for any assessment of their exact usage. Similarly, very little research has been conducted on the landscapes immediately surrounding these monuments; we cannot presently tell whether comparable acts of deposition to those evidenced at the Lewis islets also occurred at tombs. While categorising sites is, of course, useful in framing our discussions, we must also be mindful of the fact that such categories can also be blurred, internally variable and confusing.

\section{Neolithic crannogs beyond the Outer Hebrides?}

As discussed at the outset, while the Outer Hebrides represent a particularly dense hotspot for crannogs, this type of site is widespread across the rest of Scotland and Ireland. Although recent dating programmes have improved the situation dramatically (Crone 2012), only a small proportion of these sites have any associated dating evidence. Cavers (2010: 26) reported 44 radiocarbon dated crannog sites in Scotland, while Crone's (2012: 140) more recent survey listed 52, including three also dated using dendrochronology. Cavers (2010: 26) noted an additional 60 sites datable through material culture or literary references. Estimates for the total number of crannog sites in Scotland vary, depending on exactly which site types are included; most agree that many unrecorded sites remain absent from our lists (as Murray's work in Lewis clearly demonstrates). Lenfert's (2013: 123) total of 571 'island dwellings' is the most inclusive in terms of the site types it incorporates and is therefore arguably the most accurate estimate of site numbers. Combining these figures, we ascertain that approximately 10 per cent of known sites have been radiocarbon dated, with diagnostic material culture recovered from a further 10 per cent. We therefore have chronological

(C) Antiquity Publications Ltd, 2019 
information-which, it should be noted, often dates only a single phase of a site's construction or use-for approximately 20 per cent of known crannogs.

Convincing arguments can be made both in favour of and against the possibility that Neolithic crannogs may exist beyond the Outer Hebrides. First, in arguing against this suggestion, it must be emphasised that no Neolithic radiocarbon dates or material culture have so far been recovered from crannog sites elsewhere in Scotland (Cavers 2010; Crone 2012). To counter this, however, it should be noted that 80 per cent of all known sites have no associated dating evidence at all. It is also worth bearing in mind that, prior to Armit's work in the 1980s and then Murray's work in 2012-2014, no convincing Neolithic crannogs had been identified in the Outer Hebrides either; now, six sites are known. Before our in-depth work, the Neolithic origins of the five Lewis sites had been suggested only through material culture recovered from the loch beds around them-a context that has been investigated systematically at very few other sites. In Ireland, the single Late Mesolithic/Early Neolithic radiocarbon date on a timber from the crannog at Inch Island (Fredengren 2002: 120), and the sometimes very substantial quantities of Neolithic material culture recorded from some 'later' sites (O'Sullivan 1998: 59-68), suggest the possibility of Neolithic crannogs in Ireland: "it could be that the basal deposits on many Early Historic crannog sites provide an insight into the true extent of Neolithic lakeside settlement" (O'Sullivan 1998: 62).

Bearing in mind the complexities of establishing an accurate date for the earliest phases of (mostly unexcavated and often multi-phase) crannogs across Scotland (see Crone 2012), it is difficult to say much more. The Outer Hebrides, as a region, certainly could have had a coherent and strong internal dynamic during the Neolithic — as demonstrated by the very regional-specific 'Hebridean' pottery, for example. Such a dynamic could have led to a localised tradition of artificial islet construction. Yet, at the same time, the region was clearly culturally connected to mainland Scotland, Ireland and Orkney - as demonstrated by shared tomb types, imported axes and the supra-regional 'Unstan' pottery style. We should therefore certainly keep an open mind to the possibility that Neolithic islet sites could be identified elsewhere by future investigations.

\section{Summary}

Building upon Murray's initial underwater discoveries, our research has demonstrated the widespread presence of Neolithic crannogs in the Outer Hebrides, finally confirming previous scholarly speculation about the possibility of their existence (beyond Eilean Domhnuill). We have also ascertained in some detail the characteristics of two previously undiscovered sites. Our results suggest that Neolithic crannogs were not necessarily used in a uniform way across the region. The practices in evidence at, and character of, the Lewis islets forces us to reconsider the nature of Neolithic settlement, monumentality and deposition on a much broader scale. Essentially, in relation to the wider British Neolithic, this is a new type of site, which breaks down traditional site categories and further illuminates the depositional practices of that period. It is exciting to anticipate what further survey and excavation of other Neolithic crannogs across the Outer Hebrides—and possibly beyond—may reveal. 


\section{Acknowledgements}

The research described here was generously funded by the British Academy/Levehulme Trust/Honor Frost foundation and the Society of Antiquaries of London. We have benefited a great deal from the advice and support of many individuals: Deborah Anderson, Ian Armit, Mike Bamforth, Graeme Cavers, Mike Copper, Anne Crone, Aidan O'Sullivan, Joshua Pollard, Niall Sharples and Graeme Warren. We are grateful to the excavation/survey team of Jonathan Benjamin, Stephanie Blankshein, Joel Bush, Mike Copper, Crystal El Safadi, Dave Godwin, Bob Mackintosh, Chris Murray, Rodrigo Ortiz, Rodrigo Pacheco-Ruiz, Felix Pedrotti and Dan Pascoe for their hard work, good humour and multi-faceted expertise; to Michael Skelly for his logistical support; to Hugo Anderson-Whymark, Mike Copper, Anne Crone, Matt Law, Don O’Meara, Robyn Veal and staff at ORAU and SUERC for undertaking specialist analyses that have contributed significantly to our understanding of these sites; to Stephanie Blankshein and Felix Pedrotti for their dedicated work in processing the photogrammetric models; to Alison Sheridan for introducing us to these sites and for her continued support towards the project; to Kevin Murphy (Comhairle nan Eilean Siar) for his long-term support; to Donnie Macaulay, George MacLeod, Mary Macleod, Alex McDonald, Iain Maciver and the Stornoway Trust, and Margaret McKay and Lewis Island Crofters Ltd for their generosity in allowing us access to the sites; to Anwen Cooper, Mike Copper and two anonymous referees for their helpful comments on earlier versions of this paper. Finally, we would like to express our gratitude to Chris Murray for finding these sites and for all his help and generosity since then. This article is dedicated to the memory of his good friend Mark Elliot, and to George MacLeod, both of whom cared deeply about these sites.

\section{References}

ARMit, I. 1996. The archaeology of Skye and the Western Isles. Edinburgh: Edinburgh University Press.

-2003. The drowners: permanence and transience in the Hebridean Neolithic, in I. Armit, E. Murphy, E. Nelis \& D. Simpson (ed.) Neolithic settlement in Ireland and western Britain: 93-100. Oxford: Oxbow.

Bronk Ramsey, C. 2018. OxCal 4.3 manual. Available at:

http://c14.arch.ox.ac.uk/oxcalhelp/hlp_contents. html (accessed 6 March 2019).

CAvers, G. 2010. Crannogs and later prehistoric settlement in western Scotland (British

Archaeological Reports series 510). Oxford: British Archaeological Reports.

- 2012. Crannogs as buildings: the evolution of interpretation 1882-2011, in M. Midgley \& J. Sanders (ed.) Lake dwellings after Robert Munro: 169-88. Leiden: Sidestone.

Copper, M. \& I. Armit. 2018. A conservative party? Pots and people in the Hebridean Neolithic. Proceedings of the Prehistoric Society 84: 257-75. https://doi.org/10.1017/ppr.2018.12

Crone, A. 1993. Crannogs and chronologies. Proceedings of the Society of Antiquaries of Scotland 123: 245-54.

- 2012. Forging a chronological framework for Scottish crannogs; the radiocarbon and dendrochronological evidence, in M. Midgley \& J. Sanders (ed.) Lake dwellings after Robert Munro: 139-62. Leiden: Sidestone.

Cummings, V. \& C. Richards. 2013. The peristalith and the context of Calanais, in C. Richards (ed.) Building the great stone circles of the north: 186-200. Oxford: Windgather.

Dixon, N. 1989. Archaeology notes. Available at: https://canmore.org.uk/event/657207 (accessed 6 March 2019).

- 2004. The crannogs of Scotland. Stroud: Tempus.

Dixon, T. \& P. Topping. 1986. Preliminary survey of later prehistoric artificial islands on the Isle of Lewis, Outer Hebrides. International Journal of Nautical Archaeology and Underwater Exploration 15: 189-94. https://doi.org/10.1111/j.1095-9270.1986. tb00576.x

Edwards, K. \& G. Whittington. 2001. Lake sediments, erosion and landscape change during the Holocene in Britain and Ireland. Catena 42: 143-73.

https://doi.org/10.1016/S0341-8162(00) 00136-3

Fredengren, C. 2002. Crannogs. A study of people's interaction with lakes, with particular reference to Lough Gara in the north-west of Ireland. Dublin: Wordwell.

Garrow, D. \& F. Sturt. 2017. Neolithic stepping stones: excavation and survey within the western seaways of Britain, 2008-2014. Oxford: Oxbow.

(C) Antiquity Publications Ltd, 2019 
- 2019. Excavation and survey at Loch Bhorgastail and Loch Langabhat, Isle of Lewis, July 2017. Available at: http://crannogs.soton.ac.uk/neolithic-crannogs/ interim-reports (accessed 6 March 2019).

Garrow, D., S. Griffiths,

H. Anderson-Whymark \& F. Sturt. 2017a. Stepping stones to the Neolithic? Radiocarbon dating the Early Neolithic on islands within the 'western seaways' of Britain. Proceedings of the Prehistoric Society 83: 97-136. https://doi.org/10.1017/ppr.2017.4

Garrow, D., F. Sturt \& M. Copper. 2017b. Submerged Neolithic of the Western Isles interim unpublished report. Available at: http://crannogs.soton.ac.uk/neolithic-crannogs/ interim-reports (accessed 6 March 2019).

Henderson, J. 1998. Islets through time: the definition, dating and distribution of Scottish crannogs. Oxford Journal of Archaeology 17: 227-44.

https://doi.org/10.1111/1468-0092.00060

Henderson, J. \& R. Sands. 2012. Irish and Scottish crannogs, in F. Menotti \& A. O'Sullivan (ed.) The Oxford handbook of wetland archaeology: 269-82. Oxford: Oxford University Press.

Henley, C. 2003. The Outer Hebrides and the Hebridean world during the Neolithic: an island history. Unpublished PhD dissertation, Cardiff University.

- 2012. Loch a'Choire Neolithic settlement, in M. Parker Pearson (ed.) From machair to mountains: archaeological survey and excavation in South Uist: 189-98. Oxford: Oxbow.

Henshall, A. 1972. The chambered tombs of Scotland, volume 2. Edinburgh: Edinburgh University Press

LENFERT, R. 2012. Long-term continuity and change within Hebridean and mainland Scottish island dwellings. Unpublished $\mathrm{PhD}$ dissertation, University of Nottingham.

- 2013. Integrating crannogs and Hebridean island duns: placing Scottish island dwellings into context. Journal of Island and Coastal Archaeology 8: 122-43. https://doi.org/10.1080/15564894.2013. 766912

Lomax, T. 1997. Holocene vegetation history and human impact in western Lewis, Scotland. Unpublished $\mathrm{PhD}$ dissertation, University of Birmingham.

Morrison, I. 1985. Landscape with lake dwellings: the crannogs of Scotland. Edinburgh: Edinburgh University Press.

O'Sullivan, A. 1998. The archaeology of lake settlement in Ireland. Dublin: Royal Irish Academy.

Redknap, M. \& A. Lane. 1994. The early medieval crannog at Llangorse, Powys: an interim statement on the 1989-1993 seasons. International Journal of Nautical Archaeology 23: 190-205. https://doi.org/10.1111/j.1095-9270.1994. tb00460.x

Reimer, P. et al. 2013. IntCal13 and Marine13 calibration curves $0-50000$ years BP.

Radiocarbon 55: 1869-87. https://doi.org/10.2458/azu_js_rc.55.16947

Scotт, W. 1951. Eilean an Tighe: a pottery workshop of the second millennium BC. Proceedings of the Society of Antiquaries of Scotland 85: 1-37.

SHARPLES, N. 1992. Aspects of regionalisation in the Scottish Neolithic, in N. Sharples \& A. Sheridan (ed.) Vessels for the ancestors: 322-27. Edinburgh: Edinburgh University Press.

Sheridan, A., C. Murray, D. Garrow \& H. Anderson-Whymark. 2014. Spectacular Neolithic finds emerge from the lochs of Lewis. PAST 76: 1.

Received: 25 May 2018; Revised: 6 September 2018; Accepted: 9 November 2018

(C) Antiquity Publications Ltd, 2019 